\title{
International Accounting Standards and Accounting Quality
}

\author{
Mary E. Barth* \\ Graduate School of Business \\ Stanford University \\ Wayne R. Landsman and Mark H. Lang \\ Kenan-Flagler Business School \\ University of North Carolina
}

March 2006

* Corresponding author: Graduate School of Business, Stanford University, 94305-5015, mbarth@stanford.edu. We appreciate helpful comments from Ole-Kristian Hope, Steve Young, T.J. Wong, Ray Ball (editor), an anonymous referee, workshop participants at Southern Methodist University, the 2005 Pennsylvania State University Accounting Research Conference, and the 2005 Joint Journal of Accounting Research-London Business School Conference on International Financial Reporting Standards, research assistance of Yang Gui, Yaniv Konchitchki, and Christopher Williams, and funding from the Center for Finance and Accounting Research, Kenan-Flagler Business School. 


\title{
International Accounting Standards and Accounting Quality
}

\begin{abstract}
We compare characteristics of accounting amounts for firms that apply International Accounting Standards (IAS) to a matched sample of firms that do not to investigate whether applying IAS is associated with higher accounting quality and lower equity cost of capital. We find that firms applying IAS evidence less earnings management, more timely loss recognition, and more value relevance of accounting amounts than do those applying domestic GAAP. Firms applying IAS have higher variance of the change in net income, a higher ratio of the variances of the change in net income and change in cash flows, a significantly less negative correlation between accruals and cash flows, and a lower frequency of small positive net income. They have a significantly higher frequency of large negative net income and generally higher value relevance of accounting amounts. Differences between firms applying IAS and those applying domestic GAAP in the period before IAS firms adopt IAS do not explain the differences in accounting quality. Firms applying IAS generally exhibit higher accounting quality than when they previously applied domestic GAAP. The increase in accounting quality for IAS firms is generally greater than that for firms applying domestic GAAP throughout the sample period. We also find weak evidence suggesting that application of IAS is associated with a lower equity cost of capital. Overall, our results suggest improvement in accounting quality associated with applying IAS.
\end{abstract}




\section{Introduction}

We assess characteristics of accounting amounts resulting from application of International Accounting Standards (IAS) to determine whether reporting under IAS is associated with higher accounting quality and lower cost of capital. In particular, we investigate whether applying IAS is associated with less earnings management, more timely loss recognition, higher value relevance of accounting amounts, and a lower cost of capital than applying domestic Generally Accepted Accounting Principles (GAAP). We first compare characteristics of accounting amounts for firms that apply IAS and a matched sample of firms that do not in the period after the IAS firms adopt IAS. Our results suggest that firms that apply IAS have higher accounting quality than firms that do not. We next determine whether IAS firms increase accounting quality after applying IAS. Our results suggest that applying IAS is associated with improvement in accounting quality. Firms that do not apply IAS do not exhibit such improvements to the same extent over the same period. Results from analogous comparisons for equity cost of capital suggest consistent, although weaker, inferences, i.e., applying IAS may be associated with lower cost of capital. In light of the impending changes to IAS promulgated by the International Accounting Standards Board (IASB), our findings support the prospect of improvement in financial reporting as more countries and firms adopt international accounting standards. ${ }^{1}$

A primary goal of the IASB is to develop, "in the public interest, a single set of high quality, understandable and enforceable global accounting standards that require transparent and

\footnotetext{
${ }^{1}$ However, the effectiveness of IAS in the future will be a function of the evolution of the standards and their implementation. In addition, our IAS firms voluntarily adopt IAS, which raises the possibility that our inferences will not generalize to mandatory adoption of IAS. Although we control for factors that are associated with voluntary adoption by including controls in the research design and by matching IAS firms to firms that apply domestic GAAP, we cannot be sure we have eliminated the effects of self-selection in our tests. Moreover, our tests are of association, not causality.
} 
comparable information in general purpose financial statements." ${ }^{2}$ In this regard, the IASB has taken steps to remove allowable alternative accounting practices, and to require accounting measurements that better reflect a firm's economic position and performance. The IASB believes both of these actions should increase accounting quality. Accounting quality could increase if removing alternatives and increasing the extent to which accounting measurements reflect economic position limit management's discretion to report accounting amounts that are less reflective of the firm's economic position and performance, e.g., by managing earnings. Thus, we predict that accounting amounts determined in accordance with IAS are of higher quality than those determined in accordance with firms' domestic GAAP. However, because a firm's regulatory, enforcement, and attestation environment also affects accounting quality (Ball, Robin, and $\mathrm{Wu}, 2003)$, whether application of IAS results in higher quality accounting amounts is an open empirical question.

We interpret earnings that exhibit less earnings management as being of higher quality. Following prior research, our metrics of earnings management are based on the variance of the change in net income, the ratio of the variance of the change in net income to the variance of the change in cash flows, the correlation between accruals and cash flows, and the frequency of small positive net income. We interpret higher variance of the change in net income, higher ratio of the variances of the change in net income and change in cash flows, less negative correlation between accruals and cash flows, and a lower frequency of small positive net income as evidence of less earnings management. When developing our metrics, we include controls for factors that prior research identifies as being associated with firms' decisions to adopt IAS to mitigate the effects of self-selection.

\footnotetext{
${ }^{2}$ IASB Mission Statement, http://www.iasb.org/about/index.asp.
} 
We also interpret earnings that reflect losses on a more timely basis as being of higher quality. Our metric is the frequency of large negative net income, after controlling for potential confounding factors. We interpret a higher frequency of large negative net income as evidence of more timely loss recognition. Finally, we interpret accounting amounts that are more value relevant as being of higher quality. Our metrics for value relevance are the explanatory powers of income and equity book value for prices, and stock return for earnings. We interpret higher explanatory power as evidence of more value relevance.

Finally, we provide evidence on the relation between application of IAS and firms' equity cost of capital. Standard setters view cost of capital reduction as an anticipated benefit of applying IAS. ${ }^{3}$ If firms applying IAS have higher quality accounting amounts and there is a link between accounting quality and equity cost of capital, then firms applying IAS will enjoy a lower cost of capital. We estimate equity cost of capital based on the three-factor model of Fama and French (1993).

We find that in the period following adoption of IAS, i.e., the post-adoption period, firms applying IAS evidence less earnings management, more timely loss recognition, and more value relevance of accounting amounts than do firms not applying IAS. In particular, firms applying IAS have a higher variance of the change in net income, a higher ratio of the variances of change in net income and change in cash flow, a significantly less negative correlation between accruals and cash flows, and a lower frequency of small positive net income. In addition, they have a significantly higher frequency of large negative net income, significantly higher value relevance

\footnotetext{
${ }^{3}$ For example, in discussing adoption of IFRS, Bob Herz, chairman of the FASB notes, "It's about lowering the cost of capital, lowering the cost of preparation and lowering the cost of using information" (http://business.timesonline.co.uk/article/0,16649-1245761,00.html).
} 
of earnings and equity book value for share prices, and higher value relevance of earnings for good news stock returns.

Differences in our accounting quality metrics between firms applying IAS and firms that do not in the period before adoption by the firms that apply IAS, i.e., the pre-adoption period, do not explain the differences in the post-adoption period. In the pre-adoption period, quality metrics for firms that later apply IAS generally either insignificantly differ from those for firms that do not apply IAS or are consistent with lower quality. In addition, firms applying IAS generally exhibit higher accounting quality in the post-adoption period than they do in the preadoption period. Moreover, their increase in accounting quality is generally greater than that for firms that do not apply IAS, indicating that the increase in quality for firms applying IAS is not attributable to economy-wide changes between the pre- and post-adoption periods. Consistent with these findings relating to accounting quality, we also find weak supportive evidence that application of IAS is associated with a lower cost of equity capital.

There is little large-sample empirical evidence on whether applying IAS improves accounting quality. In contrast to prior research, we use a broad sample of firms in 23 countries that adopted IAS between 1994 and 2003. Prior research typically focuses on particular countries, e.g., China and Germany, and uses data from more limited time periods. There are advantages and disadvantages associated with focusing on particular countries and using shorter time periods relative to using more expansive sampling criteria. For example, focusing on a particular country removes the need to control for potentially confounding effects of countryspecific factors. However, doing so makes it difficult to extrapolate to other countries inferences from such studies. 
Existing evidence comparing the quality of accounting amounts based on applying IAS and domestic GAAP is mixed. This lack of consensus could be because such studies often use different metrics to compare accounting quality (e.g., value relevance or earnings smoothing), draw data from somewhat different time periods, and use different control variables. In contrast, we use an array of metrics drawn from a common time period and use a common set of control variables. Using a more expansive sample and an array of metrics consistently derived permits us to draw more general and reliable inferences about whether applying IAS is associated with higher accounting quality.

The remainder of our paper is organized as follows. The next section develops our hypotheses. Section three explains our research design. Section four describes our sample and data. Sections five and six present our results relating to accounting quality and equity cost of capital. Section seven offers our summary and concluding remarks.

\section{Hypothesis Development}

\subsection{IAS AND ACCOUNTING QUALITY}

The first IAS was published in 1975 by the International Accounting Standards Committee (IASC), which was formed in 1973. Since then, the process for setting international accounting standards has undergone substantial evolution, culminating in the 2001 restructuring of the IASC into the IASB. As of January 1, 2005, all publicly listed companies in the European Union are required to prepare financial statements in accordance with International Financial Reporting Standards (IFRS), and the International Organization of Securities Commissions recommends that the world's securities regulators permit foreign issuers to use IFRS for cross- 
border offerings. ${ }^{4}$ In addition, the Financial Accounting Standards Board has embarked on a comprehensive project aimed at convergence between IFRS and US GAAP.

Continuing the work of the IASC, a primary goal of IASB is to develop a single set of high quality, global accounting standards that are accepted worldwide for general purpose financial statements. To achieve this goal, the IASB limits allowable alternative accounting practices and provides a consistent approach to accounting measurement for the purpose of having a firm's recognized amounts faithfully represent its underlying economics. The IASB believes that limiting alternatives increases accounting quality because it limits management's opportunistic discretion in determining accounting amounts. The IASB also believes that accounting measurement that reflects a firm's underlying economics increases accounting quality because it provides investors with information to aid them when making investment decisions. These two sources of higher accounting quality are related in that, all else equal, limiting opportunistic discretion by managers increases the extent to which the accounting amounts reflect a firm's underlying economics. Consistent with this line of reasoning, Ewert and Wagenhofer (2005) develops a rational expectations model that shows that accounting standards that limit opportunistic discretion result in accounting earnings that are more reflective of a firm's underlying economics and, therefore, are of higher quality. Thus, we predict that accounting amounts determined in accordance with IAS are of higher quality than those determined in accordance with firms' domestic GAAP. ${ }^{5}$

\footnotetext{
${ }^{4}$ IFRS are the standards issued by the IASB. They include standards issued by the current standard setting body (the IASB) and standards issued by its predecessor (the IASC), some of which have been amended by the IASB. Because our sample period predates the effective dates of standards issued by the IASB, throughout the paper we refer to our sample firms' usage of IAS rather than the IFRS currently in place.

${ }^{5}$ Findings in Ashbaugh and Pincus (2001) also suggest that IAS are of higher quality by showing that firms using IAS exhibit smaller analyst forecast errors. In particular, the study finds that the greater the difference between domestic GAAP and IAS, the greater are the forecast errors and that forecast errors tend to be smaller after firms
} 
Although we predict that applying IAS improves accounting quality, the inherent flexibility IAS principles-based standards afford can allow firms to manage earnings, thereby decreasing accounting quality. This flexibility has long been a concern of securities markets regulators (e.g., Breeden, 1994). Even if IAS are high quality accounting standards, Cairns (1999), Street and Gray (2001), and Ball, Robin, and Wu (2003) suggest that lax enforcement can result in limited compliance with the standards, thereby limiting their effectiveness. Cairns (1999) and Street and Gray (2001) find substantial noncompliance with IAS among firms purportedly applying IAS. In particular, Street and Gray (2001) examines the 1998 financial statements for 279 firms that refer to application of IAS in their financial statements. The study examines disclosed accounting policies for consistency with major IAS pronouncements and finds that, in many cases, disclosed accounting policies are inconsistent with IAS. Ball, Robin, and $\mathrm{Wu}$ (2003) examines timely loss recognition for firms in Hong Kong, Malaysia, Singapore, and Thailand. In these countries, accounting standards are largely derived from common law and, therefore, are similar to IAS. Ball, Robin, and Wu (2003) finds that timely loss recognition for firms in these countries is no better than it is for firms in code law countries. Ball, Robin, and $\mathrm{Wu}(2003)$ attributes this finding to differing incentives of managers and auditors.

Findings in Bradshaw and Miller (2005) suggest that the regulatory and litigation environment is important to the application of accounting standards. In particular, Bradshaw and Miller (2005) studies non-US firms that assert that their domestic GAAP accounts are in accordance with US GAAP. Bradshaw and Miller (2005) finds that, although firms claiming to comply with US GAAP report accounting data more similar to US firms, the characteristics of the domestic GAAP accounting amounts often differ from those of US firms. Consistent with

adopt IAS. However, forecastable earnings are not necessarily of higher quality because, for example, smoothed earnings are typically more forecastable. 
Bradshaw and Miller (2005), findings in Lang, Raedy, and Wilson (2005) suggest that a similar litigation and regulation environment does not ensure accounting amounts of similar quality. In particular, Lang, Raedy, and Wilson (2005) examines characteristics of accounting amounts for firms that cross-list on US markets and finds that cross-listed firms' US GAAP earnings exhibit significantly more evidence of earnings management than US firms. Lang, Raedy, and Wilson (2005) finds this result despite the fact that cross-listed firms are required to use US GAAP and technically face a regulatory and litigation environment similar to US firms.

Studies comparing IAS to domestic GAAP accounting amounts in particular countries report mixed evidence on the quality of IAS relative to domestic GAAP. Comparing IAS and German GAAP, Van Tendeloo and Vanstraelen (2005) finds that German firms applying IAS do not exhibit differences in earnings management when compared to firms applying German GAAP; Daske (2006) finds no evidence of a reduction in cost of capital for German firms that apply IAS; Hung and Subramanyam (2004) finds that accounting amounts based on IAS reconciliations and German GAAP do not differ in value relevance. In contrast, Bartov, Goldberg, and Kim (2004) provides evidence that accounting earnings based on IAS are more value relevant than those based on German GAAP. Comparing IAS and Chinese GAAP, Eccher and Healy (2003) finds that accounting amounts based on IAS are not more value relevant than those based on Chinese GAAP for firms that can be owned by foreign investors. However, accounting amounts based on IAS are less value relevant than those based on Chinese GAAP for firms that can only be owned by domestic investors. The authors posit that one reason for the modest performance of IAS may be the lack of effective controls and infrastructure to monitor application of IAS. Another possible explanation for the mixed findings in this research is that firms preparing to adopt new accounting standards likely transition gradually, changing 
accounting in domestic GAAP to avoid reconciling items (Lang, Raedy, and Yetman, 2003). Consistent with a gradual transition, Hung and Subramanyam (2004) finds relatively few reconciling items related to earnings management, such as hidden reserves, which is surprising because the existence of such earnings management items is a common concern with German GAAP.

Taken together, these studies suggest that whether applying IAS improves accounting quality is an open question. They also suggest that determining the answer to the question is complicated by the need to control for the effects of factors beyond accounting standards, including regulation, enforcement, and attestation that can affect the quality of accounting amounts. As noted above, findings from studies examining whether application of IAS improves accounting quality are mixed, which could be attributable to differential effects of these factors. As described in section three, we develop empirical procedures, including matching sample and control firms and the use of multiple regression, to mitigate the effects on our inferences of regulation, enforcement, and attestation.

\subsection{MEASURES OF ACCOUNTING QUALITY}

Following prior research, we operationalize accounting quality using earnings management, timely loss recognition, and value relevance metrics. We predict firms with higher quality earnings exhibit less earnings management, more timely loss recognition, and higher value relevance of earnings and equity book value.

We examine two manifestations of earnings management, earnings smoothing and managing towards positive earnings. We expect IAS earnings to be less managed than domestic GAAP earnings because IAS limit management's discretion to report earnings that are less reflective of the firm's economic performance. Regarding earnings smoothing, following prior 
research, we assume that firms with less earnings smoothing exhibit more earnings variability (Lang, Raedy, and Yetman, 2003; Leuz, Nanda, and Wysocki, 2003; Lang, Raedy, and Wilson, 2005). We predict that firms applying IAS exhibit more variable earnings than those applying domestic GAAP. Our prediction is supported by two studies. First, Ewert and Wagenhofer (2005) shows that applying accounting standards that limit management's discretion should result in higher variability in accounting earnings. Second, Leuz, Nanda, and Wysocki (2003) finds that earnings smoothing is less pronounced in common law countries. IAS are based on a conceptual framework similar to that found in common law countries. To test our prediction, we use two measures of earnings variability, variability of change in net income and variability of change in net income relative to variability of change in cash flow.

We also assume that firms with less earnings smoothing exhibit a more negative correlation between accruals and cash flows (Lang, Raedy, and Yetman, 2003; Leuz, Nanda, and Wysocki, 2003; Lang, Raedy, and Wilson, 2005). Because accruals reverse over time, accruals and cash flows are generally negatively correlated. Land and Lang (2002) and Myers and Skinner (2002), among others, interpret a more negative correlation as indicating earnings smoothing because managers respond to poor cash flow outcomes by increasing accruals. Thus, we predict that firms applying IAS exhibit a less negative correlation between accruals and cash flows than those applying domestic GAAP.

Prior research identifies positive earnings as a common target of earnings management. Evidence of managing towards positive earnings is a larger frequency of small positive earnings (Burgstahler and Dichev, 1997; Leuz, Nanda, and Wysocki, 2003). The notion underlying this target is that management prefers to report small positive earnings rather than negative earnings. 
We expect that firms applying IAS report small positive earnings with lower frequency than those applying domestic GAAP.

Regarding timely loss recognition, we expect higher quality earnings exhibit a larger frequency of large losses. This is consistent with Ball, Kothari, and Robin (2000), Lang, Raedy, and Yetman (2003), Leuz, Nanda, and Wysocki (2003), and Lang, Raedy, and Wilson (2005) that suggest that one characteristic of higher quality earnings is that large losses are recognized as they occur rather than being deferred to future periods. This characteristic is closely related to earnings smoothing in that if earnings are smoothed, large losses should be relatively rare. Thus, we predict that firms applying IAS report large losses with higher frequency than those applying domestic GAAP.

Turning lastly to value relevance, we expect firms with higher quality earnings have a higher association between stock prices and earnings and equity book value because higher quality earnings better reflect a firm's underlying economics (Barth, Beaver, and Landsman, 2001). First, higher quality earnings are the product of applying accounting standards that require recognition of amounts that are intended to faithfully represent a firm's underlying economics. Second, higher quality earnings are less subject to opportunistic managerial discretion. These two features of higher quality earnings are linked together by Ewert and Wagenhofer (2005), which shows that accounting standards that limit opportunistic discretion result in accounting earnings that have higher value relevance. Prior empirical research also suggests that higher quality earnings are more value relevant (Lang, Raedy, and Yetman, 2003; Leuz, Nanda, and Wysocki, 2003; Lang, Raedy, and Wilson, 2005). Accordingly, we predict 
that firms applying IAS exhibit higher value relevance of earnings and equity book value than firms applying domestic GAAP. ${ }^{6}$

We examine whether firms applying IAS have higher quality earnings (and equity book value in the value relevance tests) than those applying domestic GAAP by conducting several tests relating to earnings management, timely loss recognition, and value relevance. We infer that IAS firms have higher quality earnings based on a consistent pattern of evidence provided by the portfolio of tests. An advantage of using a portfolio approach is that each test is based on different assumptions and, therefore, offers evidence that complements the others. For example, we expect that IAS firms have less discretion to smooth earnings, which should manifest as higher earnings variability relative to those firms applying domestic GAAP. However, IAS firms also have less discretion to use earnings management tools that result in higher earnings variability. One example of such a tool is taking a "big bath" in earnings to take advantage of features of the manager's compensation contract (Healy, 1985). Thus, it remains an empirical question whether IAS firms have greater earnings variability than those applying domestic GAAP.

However, assuming that investors can see through earnings management, the value relevance tests provide evidence about earnings quality even if the earnings management tests are inconclusive. Thus, for example, it is possible that IAS firms have less variable earnings, but the value relevance tests indicate that IAS firms have higher quality earnings. It also is possible

\footnotetext{
${ }^{6}$ Examining value relevance in this context is subject to at least two caveats. First, it presumes the pricing process is similar across firms and across countries, after we match on and control for firm size, country, and industry. For example, Eccher and Healy (2003) provides evidence that prices reflect investor clienteles that can differ across firms and countries. Second, earnings smoothing can increase the association between earnings and share prices. For example, the presence of large asset impairments is likely to be positively associated with frequency of large negative net income, but could reduce the value relevance of accounting earnings because extreme losses tend to have a low correlation with share prices and returns. See Wysocki (2005) for a discussion of various approaches to assessing accounting quality.
} 
that IAS firms exhibit more variable earnings that the market deems to be of lower quality, as indicated by the value relevance tests. For example, IAS requires recognition of many financial instruments at fair value that may be difficult to estimate, which is reflected as noise in earnings. We would interpret this mixed evidence as being inconclusive regarding earnings quality for IAS firms.

\section{Research Design}

To test our predictions, we first compare firms that apply IAS, "IAS firms," to a matched sample of firms that instead only apply domestic GAAP, "NIAS firms," in the period after the IAS firms adopt IAS, i.e., in the post-adoption period. This permits us to test whether IAS firms evidence higher accounting quality than NIAS firms. We predict that they do. However, it is possible that despite our matching procedure described below, IAS and NIAS firms exhibit differences in accounting quality in the post-adoption period because they differ before the IAS firms adopt IAS, i.e., in the pre-adoption period. To determine whether this is the case, we compare IAS and NIAS firms' accounting quality in the pre-adoption period.

To assess whether application of IAS is associated with changes in accounting quality, we next compare accounting quality for IAS firms in the pre-adoption and post-adoption periods. We predict that IAS firms have higher quality accounting amounts in the post-adoption period than they do in the pre-adoption period. Finally, findings in Land and Lang (2002) suggest that accounting quality may be improving worldwide. It also is possible that changes in general economic factors, including enforcement and attestation, could account for improvement in accounting quality for IAS firms. To assess whether changes in accounting quality for IAS firms reflect changes other than the application of IAS, we compare changes in accounting quality for 
IAS firms between the pre-adoption and post-adoption periods to those of NIAS firms. We predict that accounting quality for IAS firms increases more than for NIAS firms.

Consistent with Lang, Raedy, and Yetman (2003) and Lang, Raedy, and Wilson (2005) but modified to our context, we identify each IAS firm's country, industry (i.e., three-digit SIC code) and adoption year. We then identify all firms that have not adopted IAS in any sample year. We select the non-adopting firm whose equity market value is closest to the IAS firm's at the end of its adoption year to serve as the matched NIAS firm. Once a non-adopting firm is selected as a match, it is not considered as a potential match for other IAS firms. In a few cases, potential matching firms do not have market value of equity available in the adoption year. In those cases, we consider market value of equity for the two years before and after the adoption year. ${ }^{7}$ Our analyses include all firm-years for which the IAS firm and its matched NIAS firm both have data. For example, if the IAS firm has data from 1994 through 2000, and its matched NIAS firm has data for 1995 through 2002, then our analysis includes data from 1995 through 2000 for the IAS firm and its matched NIAS firm.

Similar to studies examining differences between cross-listed and other firms (e.g., Lang, Raedy, and Yetman, 2003; Lang, Raedy, and Wilson, 2005), it is possible that firms' decisions to adopt IAS are associated with underlying firm characteristics that are not controlled by our matching procedure. Thus, failure to control for a firm's tendency to adopt IAS can lead to endogeneity bias when we compare accounting quality differences of firms that apply IAS and those that do not. Our research design contains two additional features beyond using a matched sample that mitigate the effects of this endogeneity bias. First, we include controls for factors

\footnotetext{
${ }^{7}$ We also used other matching procedures, i.e., permitting an NIAS firm to be matched to more than one IAS firm and only requiring NIAS firms to have market value of equity in the IAS firm's year of adoption. Our inferences are the same using these alternative procedures.
} 
that could be associated with firms' IAS adoption decisions, e.g., growth and leverage. ${ }^{8}$ Second, we use each firm as its own control when we compare characteristics of IAS firms' accounting amounts before and after IAS adoption.

\subsection{EARNINGS MANAGEMENT}

Our first earnings management measure is based on the variability of the change in net income scaled by total assets, $\Delta N I$ (Lang, Raedy, and Wilson, 2005). ${ }^{9}$ A smaller variance of the change in net income is interpreted as evidence of earnings smoothing. However, net income is likely to be sensitive to a variety of factors related to firms' incentives to adopt IAS that are unrelated to earnings smoothing. Although our matching procedure mitigates the confounding effects of these factors, some effects may remain. Therefore, our measure of earnings variability is the variance of the residuals from the regression of change in net income on control variables identified in prior research (Ashbaugh, 2001; Pagano, Röell, and Zehner, 2002; Lang, Raedy, and Yetman, 2003; Lang, Raedy, and Wilson, 2005; Tarca, 2005), $\Delta N I^{*}$ :

$$
\begin{aligned}
\Delta N I_{i t}= & \alpha_{0}+\alpha_{1} S_{Z Z E_{i t}}+\alpha_{2} \text { GROWTH }_{i t}+\alpha_{3} \text { EISSUE }_{i t}+\alpha_{4} \text { LEV }_{i t}+ \\
& \alpha_{5} \text { DISSUE }_{i t}+\alpha_{6} \operatorname{TURN}_{i t}+\alpha_{7} \text { CF }_{i t}+\alpha_{8} \text { AUD }_{i t}+\alpha_{9} \operatorname{NUMEX}_{i t}+ \\
& \alpha_{10} \text { XLIST }_{i t}+\alpha_{11} \operatorname{CLOSE}_{i t}+\varepsilon_{i t} .
\end{aligned}
$$

SIZE is the natural logarithm of end of year market value of equity, GROWTH is percentage change in sales, EISSUE is percentage change in common stock, $L E V$ is end of year total liabilities divided by end of year equity book value, DISSUE is percentage change in total liabilities, TURN is sales divided by end of year total assets, $C F$ is annual net cash flow from

\footnotetext{
${ }^{8}$ Inferences are not sensitive to the inclusion of the controls.

${ }^{9}$ DataStream provides several definitions of operating income. The one we use does not include extraordinary items and other non-operating income. However, because the criterion for extraordinary items differs across countries and excluding extraordinary items could result in differences based on the location on the income statement of one-time items, we replicate the analysis including extraordinary and non-operating items. Our inferences are unaffected.
} 
operating activities, $A U D$ is an indicator variable that equals one if the firm's auditor is $\mathrm{PwC}$, KPMG, Arthur Andersen, E\&Y, or D\&T, and zero otherwise, NUMEX is the number of exchanges on which a firm's stock is listed, XLIST is an indicator variable that equals one if the firm is listed on any US stock exchange and WorldScope indicates that the US exchange is not the firm's primary exchange, and CLOSE is the percentage of closely held shares of the firm as reported by WorldScope. Equation (1) also includes country and industry fixed effects, as do equations (2) through (8).

We estimate equation (1) pooling observations that are relevant to the particular comparison we test. For example, when comparing IAS and NIAS firms in the post-adoption period, we pool all sample years in the post-adoption period. For this comparison, the variability of $\Delta N I^{*}$ is the cross-sectional variance of IAS and NIAS firms' respective residuals from equation (1) in the post-adoption period. When comparing IAS firms in the post- and preadoption periods, we pool all sample years for IAS firms. For this comparison, the variability of $\Delta N I^{*}$ is the respective cross-sectional variance of residuals for IAS firms in the post- and preadoption periods. We test for differences in these variances using a variance ratio F-test. We compare the difference in the variability of $\Delta N I^{*}$ between the pre- and post-adoption periods for IAS and NIAS firms as the difference between the resulting measures for IAS and NIAS firms.

Our second measure of earnings smoothing is based on the ratio of the variability of the change in net income, $\Delta N I$, to the variability of the change in operating cash flows, $\Delta C F$. Firms with more volatile cash flows typically have more volatile net income, and our second measure controls for this. If firms use accruals to manage earnings, the variability of the change in net income should be lower than that of operating cash flows. As with $\Delta N I, \triangle C F$ is likely to be sensitive to a variety of factors related to firms' incentives to adopt IAS that are unrelated to 
earnings smoothing. Therefore, we also estimate an equation similar to equation (1), but with $\triangle C F$ as the dependent variable:

$$
\begin{aligned}
\Delta C F_{i t}= & \alpha_{0}+\alpha_{1} \operatorname{SIZE}_{i t}+\alpha_{2} \text { GROWTH }_{i t}+\alpha_{3} \text { EISSUE }_{i t}+\alpha_{4} L E V_{i t}+ \\
& \alpha_{5} \text { DISSUE }_{i t}+\alpha_{6} \operatorname{TURN}_{i t}+\alpha_{7} \mathrm{CF}_{i t}+\alpha_{8} A U D_{i t}+\alpha_{9} \text { NUMEX }_{i t}+ \\
& \alpha_{10} \mathrm{XLIST}_{i t}+\alpha_{11} \operatorname{CLOSE}_{i t}+\varepsilon_{i t}
\end{aligned}
$$

As with equation (1), we pool observations appropriate for the particular comparison. The variability of $\triangle C F^{*}$ is the cross-sectional variance of groups of residuals from equation (2), where the composition of the groups depends on the particular comparison we test. Our resulting second measure is the ratio of the variability of $\Delta N I^{*}$ to variability of $\Delta C F^{*}$. As in Lang, Raedy, and Wilson (2005), we do not test the differences between IAS and NIAS firms' ratios of variances because we are unaware of any statistical test for differences in them.

Our third measure of earnings smoothing is based on the Spearman correlation between accruals and cash flows. As with the two variability measures based on equations (1) and (2), because our matching procedure may not eliminate the sensitivity of the accruals and cash flows correlation to factors unrelated to earnings smoothing, we compare correlations of residuals from equations (3) and (4), $C F^{*}$ and $A C C^{*}$, rather than correlations between $C F$ and $A C C$ directly. As with the equations (1) and (2), both $C F$ and $A C C$ are regressed on the control variables, but excluding $C F$ :

$$
\begin{aligned}
C F_{i t}= & \alpha_{0}+\alpha_{1} \text { SIZE }_{i t}+\alpha_{2} \text { GROWTH }_{i t}+\alpha_{3} \text { EISSUE }_{i t}+\alpha_{4} L E V_{i t}+ \\
& \alpha_{5} \text { DISSUE }_{i t}+\alpha_{6} \text { TURN }_{i t}+\alpha_{7} \text { AUD }_{i t}+\alpha_{8} N U M E X_{i t}+ \\
& \alpha_{9} \text { XLIST }_{i t}+\alpha_{10} \text { CLOSE }_{i t}+\varepsilon_{i t} \\
A_{C C}= & \alpha_{0}+\alpha_{1} \text { SIZE }_{i t}+\alpha_{2} \text { GROWTH }_{i t}+\alpha_{3} \text { EISSUE }_{i t}+\alpha_{4} L E V_{i t}+ \\
& \alpha_{5} \text { DISSUE }_{i t}+\alpha_{6} \text { TURN }_{i t}+\alpha_{7} \text { AUD }_{i t}+\alpha_{8} N U M E X_{i t}+ \\
& \alpha_{9} \text { XLIST }_{i t}+\alpha_{10} \text { CLOSE }_{i t}+\varepsilon_{i t}
\end{aligned}
$$


We test for differences in the correlations between $C F^{*}$ and $A C C^{*}$ based on the squared correlation as derived in Cramer (1987).

Our measure of managing towards positive earnings is the coefficient on small positive net income, SPOS, in equations (5) and (6). When comparing IAS firms and NIAS firms in the post-adoption (pre-adoption) period, we estimate equation (5) pooling observations from the post-adoption (pre-adoption) period.

$$
\begin{aligned}
\operatorname{IAS}(0,1)_{i t}= & \alpha_{0}+\alpha_{1} \operatorname{SPOS}_{i t}+\alpha_{2} \text { SIZE }_{i t}+\alpha_{3} \text { GROWTH }_{i t}+\alpha_{4} \text { EISSUE }_{i t}+ \\
& \alpha_{5} \text { LEV }_{i t}+\alpha_{6} \text { DISSUE }_{i t}+\alpha_{7} \text { TURN }_{i t}+\alpha_{8} C_{i t}+\alpha_{9} A U D+ \\
& \alpha_{10} \text { NUMEX }_{i t}+\alpha_{11} X L I S T+\alpha_{12} C L O S E_{i t}+\varepsilon_{i t}
\end{aligned}
$$

$\operatorname{IAS}(0,1)$ is an indicator variable that equals one for IAS firms and zero for NIAS firms, and $S P O S$ is an indicator variable that equals one if net income scaled by total assets is between 0 and 0.01 (Lang, Raedy, and Yetman, 2003). A negative coefficient on SPOS suggests that NIAS firms manage earnings toward small positive amounts more frequently than do IAS firms. We use the coefficient on SPOS from equation (5) rather than directly comparing the IAS and NIAS firms' percentages of small positive income to assess whether IAS firms are less likely to manage earnings because the matching procedure may not eliminate differences in economic factors associated with firms adopting IAS.

When comparing IAS firms in the post-adoption and pre-adoption periods, we estimate equation (6) pooling IAS firm observations from all sample years.

$$
\begin{aligned}
\operatorname{POST}(0,1)_{i t}= & \alpha_{0}+\alpha_{1} \operatorname{SPOS}_{i t}+\alpha_{2} \text { SIZE }_{i t}+\alpha_{3} \text { GROWTH }_{i t}+\alpha_{4} \text { EISSUE }_{i t}+ \\
& \alpha_{5} \text { LEV }_{i t}+\alpha_{6} \text { DISSUE }_{i t}+\alpha_{7} \text { TURN }_{i t}+\alpha_{8} C F_{i t}+\alpha_{9} \text { AUD }_{i t}+ \\
& \alpha_{10} \text { NUMEX }_{i t}+\alpha_{11} \text { XLIST }_{i t}+\alpha_{12} \text { CLOSE }_{i t}+\varepsilon_{i t}
\end{aligned}
$$

$\operatorname{POST}(0,1)$ is an indicator variable that equals one for observations in the post-adoption period and zero otherwise. A negative coefficient on SPOS suggests that IAS firms manage earnings 
toward small positive amounts more frequently in the pre-adoption period than they do in the post-adoption period. ${ }^{10}$

\subsection{TIMELY LOSS RECOGNITION}

We measure timely loss recognition as the coefficient on the percentage of large negative net income, $L N E G$, in equations (7) and (8) (Lang, Raedy, and Yetman, 2003; Lang, Raedy, and Wilson, 2005). When comparing IAS firms and NIAS firms in the post-adoption (pre-adoption) period, we estimate equation (7) pooling observations from the post-adoption (pre-adoption) period.

$$
\begin{aligned}
\operatorname{IAS}(0,1)_{i t}= & \alpha_{0}+\alpha_{1} N L E G_{i t}+\alpha_{2} \operatorname{SIZE}_{i t}+\alpha_{3} \text { GROWTH }_{i t}+\alpha_{4} \text { EISSUE }_{i t}+ \\
& \alpha_{5} \text { LEV }_{i t}+\alpha_{6} \text { DISSUE }_{i t}+\alpha_{7} \operatorname{TURN}_{i t}+\alpha_{8} C F_{i t}+\alpha_{9} A U D_{i t}+ \\
& \alpha_{10} \text { NUMEX }_{i t}+\alpha_{11} \text {XLIST }_{i t}+\alpha_{12} \text { CLOSE }_{i t}+\varepsilon_{i t}
\end{aligned}
$$

$L N E G$ is an indicator variable that equals one for observations for which annual net income scaled by total assets is less than -0.20 , and zero otherwise. A positive coefficient on $L N E G$ suggests that IAS firms recognize large losses more frequently than NIAS firms. As with equation (5), we use the coefficient on $L N E G$ from equation (7) rather than directly comparing IAS and NIAS firms' percentages of large losses to assess whether IAS firms are less likely to manage earnings.

When comparing IAS firms in the post-adoption and pre-adoption periods, we estimate equation (8) pooling IAS firm observations from all sample years.

$$
\begin{aligned}
\operatorname{POST}(0,1)_{i t}= & \alpha_{0}+\alpha_{1} N_{L E G_{i t}}+\alpha_{2} \operatorname{SIZE}_{i t}+\alpha_{3} \text { GROWTH }_{i t}+\alpha_{4} \text { EISSUE }_{i t}+ \\
& \alpha_{5} L E V_{i t}+\alpha_{6} \text { DISSUE }_{i t}+\alpha_{7} \operatorname{TURN}_{i t}+\alpha_{8} C F_{i t}+\alpha_{9} A U D_{i t}+ \\
& \alpha_{10} \operatorname{NUMEX}_{i t}+\alpha_{12} \mathrm{XLIST}_{i t}+\alpha_{12} \mathrm{CLOSE}_{i t}+\varepsilon_{i t}
\end{aligned}
$$

\footnotetext{
${ }^{10}$ In the analyses of small positive and large negative net income, we report results from OLS estimation rather than from a logit estimation because the model rejects the test for homoskedasticity. Greene (1993) reports that logit models are extremely sensitive to the effects of heteroscedasticity.
} 
A positive coefficient on $L N E G$ suggests that IAS firms recognize large losses more frequently in the post-adoption period than they do in the pre-adoption period. For SPOS and $L N E G$, we test for differences between the SPOS and $L N E G$ coefficients for IAS and NIAS firms based on equations (6) and (8) by pooling all observations, permitting each variable in the two equations to differ for IAS and NIAS firms.

\subsection{VALUe ReLeVANCE}

The first value relevance measure is based on the explanatory power from a regression of stock price on earnings and equity book value. To obtain a measure of value relevance that is unaffected by differences in value relevance across countries and industries, we first regress stock price, $P$, on country and industry fixed effects. We regress the residuals from this regression, $P^{*}$, on equity book value per share, $B V E P S$, and net income per share, NIPS, separately for IAS and NIAS firms in both the post- and pre-adoption periods, i.e., we estimate four regressions. Following prior research, to ensure accounting information is in the public domain, we measure $P$ six months after fiscal year-end (Lang, Raedy, and Yetman, 2003; Lang, Raedy, and Wilson, 2005). Our first value relevance measure is the adjusted $\mathrm{R}^{2}$ from equation (9).

$$
P^{*}{ }_{i t}=\beta_{0}+\beta_{1} B V E P S_{i t}+\beta_{2} N I P S_{i t}+\varepsilon_{i t}
$$

We test for significance in difference of $\mathrm{R}^{2} \mathrm{~s}$ in all value relevance tests based on the Cramer (1987) test.

Our second and third value relevance measures are based on the explanatory power from regressions of net income per share on annual stock return. Ball, Kothari, and Robin (2000) predicts that accounting quality differences will be most pronounced for "bad news" because when firms have "good news" they have less incentive to manage earnings. Thus, we estimate 
the earnings-returns relation separately for positive and negative return subsamples. Because we partition firms based on the sign of the return, we estimate two "reverse" regressions with earnings as the dependent variable, where one is for good news firms and the other is for bad news firms. As with the first value relevance measure, to obtain good and bad news value relevance measures that are unaffected by differences in value relevance across countries and industries, we first regress net income per share, $N I / P$, on country and industry fixed effects. We regress the residuals from this regression, $N I / P^{*}$, on annual stock return, $R E T U R N$, the twelvemonth stock return commencing nine months before fiscal year end and ending three months after fiscal year end (Lang, Raedy, and Wilson, 2005). Our second and third value relevance measures are the $\mathrm{R}^{2}$ s from equation (10) estimated for good news and bad news firms.

$$
[N I / P]_{i t}^{*}=\beta_{0}+\beta_{1} R E T U R N_{i t}+\varepsilon_{i t}
$$

As with equation (9), we estimate equation (10) separately for IAS and NIAS firms in both the post- and pre-adoption periods.

\section{Data}

Our sample comprises 1,885 firm year observations for 319 firms that adopted IAS between 1994 and 2003 for which DataStream data are available from 1990 through 2003. Obtaining data beginning in 1990 provides us with a minimum of four years of pre-adoption period data. We obtain our sample of IAS firms from Worldscope, and gather financial and accounting data from DataStream. The sample size reflects our having winsorized at the 5\% level all variables used to construct our metrics to mitigate the effects of outliers on our inferences.

Table 1, panel A, presents the country breakdown of our sample. In general, the sample is from a wide range of countries, with greatest representation from Switzerland, China, and 
Germany. ${ }^{11}$ Panel B of table 1 presents the sample industry breakdown. The sample comprises a range of industries, with most in manufacturing, finance, insurance and real estate, or services. Our matching procedure is designed to control for industry differences. Panel C of table 1 presents a sample breakdown by IAS adoption year, and reveals variation across years.

Table 2 presents descriptive statistics relating to variables used in our analyses. Table 2 reveals that IAS firms have significantly fewer incidents of small positive earnings and insignificantly more incidents of large negative earnings than do NIAS firms. ${ }^{12}$ Although these descriptive statistics do not control for other factors, they suggest that IAS firms are less likely than NIAS firms to manage earnings towards a target and more likely to recognize losses in a timely manner. In terms of control variables, although IAS firms have higher growth than do NIAS firms, the difference is not significant. Despite the size match, IAS firms are significantly larger than NIAS firms. Further, there is some evidence that IAS firms are more likely to issue debt (mean but not median difference is significant), more likely to issue equity (median but not mean difference is significant), and are less highly levered (mean but not median difference is significant). Relating to the last four control variables, on average, IAS firms trade on more exchanges than NIAS firms, are more likely to be audited by one of the large auditing firms, are more likely to list on a US stock exchange, and have a smaller percentage of closely held shares. All of these differences are significant.

\footnotetext{
${ }^{11}$ Our sample of Chinese and German firms includes some firms that are required to apply IAS. These include Chinese B share firms and German New Market firms. We perform all of our comparisons omitting these firms. None of the inferences differs from those obtained from the tabulated results. The table 1, panel A, country classification includes firms from the listed country that are incorporated off-shore, e.g., in Bermuda. The off-shore incorporation permits these firms to use IAS rather than domestic GAAP. For example, four UK firms are headquartered and operate in the UK, but are incorporated in Bermuda.

${ }^{12}$ With the exception of the descriptive statistics in table 2 for which statistical significance is assessed using a twosided alternative, throughout we use a 5\% significance level to assess statistical significance based on a one-sided alternative.
} 


\section{Results}

\subsection{POST-AdOPTION PERIOD}

Table 3 presents results comparing quality of accounting amounts for IAS and NIAS firms in the post-adoption period. It reveals that firms applying IAS evidence less earnings management, more timely loss recognition, and more value relevance of accounting amounts than do firms not applying IAS.

\subsubsection{EARNINGS MANAGEMENT}

The first finding relating to earnings management indicates that IAS firms exhibit higher variability of change in net income, $\Delta N I^{*}, 0.0025$ versus 0.0021 , although the difference is not significant. The second finding is consistent with the first in that it indicates that the ratio of the variance of change in net income, $\Delta N I^{*}$, to the variance of change in cash flow, $\triangle C F^{*}$, is higher for IAS firms than for NIAS firms. In particular, the ratios are 1.1076 and 1.0392 for IAS and NIAS firms, suggesting that the difference in net income variability is not solely a result of a difference in cash flow variability. Consistent with the first two measures, the third finding indicates that the correlation between accruals, $A C C^{*}$, and cash flow, $C F^{*}$, for IAS firms, -0.5518 , is significantly less negative than for NIAS firms, -0.5697 . This finding suggests that IAS firms smooth earnings less than NIAS firms. Finally, the coefficient on $S P O S,-0.0431$, is negative, although not significantly so, which suggests that NIAS firms more frequently report small positive earnings, consistent with managing earnings towards an earnings target.

\subsubsection{TIMELY LOSS RECOGNITION}

The next finding in table 3 relates to timely loss recognition. The significantly positive coefficient on $L N E G, 0.1424$, suggests that, controlling for other factors, IAS firms recognize large losses more frequently than NIAS firms. This finding suggests that relative to IAS firms, 
NIAS firms smooth earnings by delaying the effects of large negative outcomes. In particular, one interpretation of the results relating to SPOS and $L N E G$ is that managers of NIAS firms smooth away from large negative earnings and toward small positive earnings, resulting in less timely recognition of losses.

\subsubsection{VALue ReLEVAnCE}

The final set of findings in table 3 relates to value relevance of accounting amounts. First, regressions of price on earnings and equity book value for IAS and NIAS firms reveal that the $\mathrm{R}^{2}$ for IAS firms is significantly greater than that for NIAS firms, $40.23 \%$ versus $30.35 \%$. Untabulated regression summary statistics indicate that, as expected, the coefficients on earnings and equity book value are significantly positive for both IAS and NIAS firms, and that both coefficients are smaller for NIAS firms. These findings also are consistent with accounting amounts being more value relevant for IAS than for NIAS firms. Consistent with predictions, $\mathrm{R}^{2} \mathrm{~s}$ for IAS firms are greater for good news firms (4.90\% versus $2.14 \%$ ), although the difference is not significant. Contrary to predictions, the $\mathrm{R}^{2} \mathrm{~s}$ for bad news IAS firms are lower than for bad news NIAS firms $(6.22 \%$ versus $7.39 \%)$, although the difference is not significant. ${ }^{13}$

\subsection{Pre-Adoption PERIOD}

Table 4 presents findings for earnings management, timely loss recognition, and value relevance for IAS and NIAS firms in the pre-adoption period. It reveals that differences in our accounting quality metrics between IAS and NIAS firms in the pre-adoption period do not explain the post-adoption period differences in table 3.

\footnotetext{
${ }^{13}$ The fact that we do not find significantly greater explanatory power for bad news IAS firms is somewhat surprising given previous evidence on timely loss recognition (Ball, Robin, and $\mathrm{Wu}, 2003$ ). The finding is also contrary to our finding that IAS firms have a greater frequency of large negative net income than NIAS firms.
} 


\subsubsection{EARNINGS MANAGEMENT}

The first finding relating to earnings management indicates that IAS firms exhibit a significantly lower variance of the change in net income, $\Delta N I^{*}$, than NIAS firms in the preadoption period, 0.0016 versus 0.0018 . This finding contrasts with that from the post-adoption period in which IAS firms have an insignificantly higher variance of $\Delta N I^{*}$. This result suggests that the higher $\Delta N I^{*}$ variance for IAS firms in table 3 in the post-adoption period is not a result of higher $\Delta N I^{*}$ variance for IAS firms in the pre-adoption period. The second finding indicates that the ratio of the variance of change in net income, $\Delta N I^{*}$, to the variance of the change in cash flow, $\triangle C F^{*}$, is higher for NIAS firms than for IAS firms, 0.6661 versus 0.6194 . This result suggests that IAS firms evidence more earnings smoothing than NIAS firms in the pre-adoption period. This finding is in contrast to the finding for the post-adoption period, in which NIAS firms have a lower ratio of the two variances, indicating that IAS firms evidence less earnings smoothing in the post-adoption period. This difference indicates that the higher ratio of the variances of $\triangle N I^{*}$ to $\triangle C F^{*}$ in table 3 in the post-adoption period is not a result of a higher ratio for IAS firms in the pre-adoption period. The third finding indicates that the correlations between accruals, $A C C^{*}$, and cash flow, $C F^{*}$, are significantly more negative for IAS firms than for NIAS firms, -0.6073 versus -0.5726 , which also indicates that IAS firms evidence more earnings smoothing than NIAS firms in the pre-adoption period.

Finally, the coefficient on $S P O S,-0.0713$, is insignificantly different from zero in the pre-adoption period, which suggests that NIAS and IAS firms report small positive earnings with similar frequencies in the pre-adoption period. 


\subsubsection{TIMELY LOSS RECOGNITION}

The next finding in table 4 relates to timely loss recognition. It indicates that the $L N E G$ coefficient, 0.3094 , is significantly larger for IAS than NIAS firms. The result provides evidence that IAS firms recognize losses more frequently even in the pre-adoption period.

\subsubsection{VALUe ReLEVANCE}

The final set of findings in table 4 relates to value relevance. Regressions of price on earnings and equity book value for IAS and NIAS firms reveal that the $\mathrm{R}^{2}$ for IAS firms is significantly larger than that for NIAS firms, $28.03 \%$ versus $27.18 \%$, in the pre-adoption period. Thus, it is possible that the higher value relevance in the post-adoption period evidenced by price regressions for IAS firms is attributable to their having higher value relevance before applying IAS. The $\mathrm{R}^{2}$ from a regression of earnings on returns for good news IAS firms, $2.24 \%$, is significantly smaller than that for good news NIAS firms, $2.99 \%$. This finding suggests that the higher value relevance for good news IAS firms in the post-adoption period is not attributable to differences in the pre-adoption period. In contrast, the $\mathrm{R}^{2}$ for bad news IAS firms, $4.64 \%$, is significantly higher than that for NIAS firms, $1.84 \%$. We interpret this finding in connection with the findings in tables 5 and 6.

\subsection{COMPARISON OF POST- AND PRE-Adoption PERIOdS FOR IAS FiRMS}

Overall, results for the pre-adoption period provide little evidence that the results in the post-adoption period were also in evidence prior to the application of IAS. To investigate more directly whether our post-adoption results reflect pre-existing differences or the effect of changes 
associated with applying IAS, we conduct an analysis of changes in our measures before and after the IAS firms adopt IAS. ${ }^{14}$

Table 5 presents a comparison of findings for earnings management, timely loss recognition, and value relevance for IAS firms in the pre- and post-adoption periods. Tests for all measures suggest improvements in accounting quality with application of IAS. In particular, variability of net income increases significantly from 0.0017 to 0.0024 , and variability of net income relative to that of cash flow also increases from 0.7442 to 0.9980 . In addition, the correlation between accruals and cash flows after adoption, -0.5549 , is significantly less negative than before adoption, -0.5726 . Similarly, as indicated by the SPOS coefficient of -0.0645 , the proportion of small positive net income decreases after adoption, although this decrease is insignificant.

Regarding timely loss recognition, as indicated by the significant $L N E G$ coefficient of 0.1805 , the proportion of large negative earnings is significantly higher post-adoption than preadoption. The $\mathrm{R}^{2} \mathrm{~s}$ from the price level regressions and from the good and bad news returns regressions also increase significantly from $28.20 \%, 2.24 \%$, and $4.64 \%$ in the pre-adoption period to $40.23 \%, 4.90 \%$, and $6.22 \%$ in the post-adoption period.

\subsection{DIFFERENCE IN CHANGES FOR IAS AND NIAS FIRMS}

A limitation of the analysis in table 5 is that it is difficult to infer whether the improvement in accounting quality we observe for IAS firms is the result of applying IAS, or

\footnotetext{
${ }^{14}$ Although this analysis has the advantage of using the firm as its own control, three caveats apply. First, because there are different numbers of pre- and post-adoption years for firms in our sample, the pre- and post-adoption panels are unbalanced in terms of number of observations. Second, if firms transition gradually to IAS, some of the observations before and after adoption will be confounded, potentially weakening our results. Third, it is possible that some of the effects of IAS also manifest in non-IAS firms because of, for example, domestic GAAP changing to be more similar to IAS, potentially understating the effects of IAS for IAS firms relative to NIAS firms. Table 6 investigates the extent to which changes in accounting quality for NIAS firms before and after IAS firms adopt IAS affect our inferences.
} 
whether NIAS firms experienced similar improvement in accounting quality over the same time period. The results in table 6 generally support the hypothesis that IAS firms experience a greater improvement in accounting quality than NIAS firms between the pre- and post-adoption periods. In particular, differences in changes for three of the four earnings management measures and two of the $\mathrm{R}^{2}$ measures are in the predicted direction. The difference in changes for the variability of change in $\Delta N I^{*}$ is significant. Only managing to a target, timely loss recognition, and bad news $\mathrm{R}^{2}$ differences in changes results are contrary to predictions.

\section{Applying IAS and Equity Cost of Capital}

Next we consider whether applying IAS is associated with lower equity cost of capital. Findings from the information economics literature provide theoretical links between accounting information and the cost of capital arising from information asymmetry. Easley and O'Hara (2004) develops an asset pricing model in which both public and private information affect asset returns, thereby linking a firm's information structure to its cost of capital. A key result of the model is that firms can influence their cost of capital by affecting the precision and quantity of information available to investors. In particular, the authors note "this can be accomplished by a firm's selection of its accounting standards, as well as through its corporate disclosure policies." Relatedly, Amihud and Mendelson (1986) develops an asset pricing model in which investors require a liquidity premium to compensate them for the costs of trading in a firm's securities. In addition, several studies, relying on somewhat different assumptions, link information and cost of capital by suggesting that increased information provided by financial disclosure can reduce estimation risk, thereby lowering cost of capital (Klein and Bawa, 1977; Barry and Brown, 1985; Coles and Loewenstein, 1988; Clarkson and Thompson, 1990; Handa and Linn, 1993). 
Other studies provide empirical evidence linking accounting quality and equity cost of capital. Botosan (1997) and Botosan and Plumlee (2002) provide evidence that proxies for expected cost of equity capital are negatively related to the voluntary disclosure level as measured by AIMR corporate disclosure scores. Francis, et al. (2004) relates measures of earnings quality to proxies for equity cost of capital. Bhattacharya, Daouk, and Welker (2003) finds a link between three earnings quality measures (earnings aggressiveness, loss avoidance, and earnings smoothing) and a proxy for equity cost of capital in country-level tests. Barth, Konchitchki, and Landsman (2006) provides evidence that a timely measure of accounting quality is significant incremental to the Fama-French factors in a returns prediction model, and is correlated with expected equity cost of capital constructed from a three-factor Fama-French approach similar to the one used here.

Collectively, the theoretical and empirical research linking accounting quality and equity cost of capital leads us to predict that applying IAS is associated with lower equity cost of capital. We test this prediction by comparing our estimate of expected equity cost of capital for IAS firms in the pre- and post-adoption periods, using NIAS firms to control for intertemporal changes in expected equity cost of capital unrelated to applying IAS.

\subsection{ESTIMATION OF EXPECTED Equity COST OF CAPITAL}

Botosan and Plumlee (2002) infers cost of capital from share price and earnings forecasts. Because we do not have earnings forecasts for most sample firms, we follow the approach in Griffin (2002), Ang and Liu (2004), and Massa, Peyer, and Tong (2004) in estimating expected equity cost of capital using the Fama and French (1993) three-factor model. That model expresses the firm's equity return in excess of the risk-free rate of return, $R_{i}-R_{f}$, as a linear 
function of the excess return of the market portfolio, $R_{M}-R_{f}$, and the return on the high minus low book-to-market ( $H M L)$ and small-minus-big ( $S M B)$ factor mimicking portfolios.

Our procedure for estimating expected equity cost of capital has two steps. First, we estimate the sensitivity of each firm $i$ 's return to each of the three Fama-French factors by estimating firm by firm the following monthly time-series regression:

$$
R E T_{i, m}-R_{f, m}=\alpha_{i}+\beta_{R M R F, i}\left(R_{M, m}-R_{f, m}\right)+\beta_{H M L, i}\left(H M L_{m}\right)+\beta_{S M B, i}\left(S M B_{m}\right)+\varepsilon_{i, m},
$$

where $R E T_{i, m}-R_{f, m}$ is firm $i$ 's monthly stock return in excess of the risk-free rate, and $\beta_{R M R F, i}$, $\beta_{H M L, i}$, and $\beta_{S M B, i}$ are the factor coefficients. We estimate equation (11) using the most recent 60 months' returns, if available, prior to the beginning of firm $i$ 's fiscal year $t$. For fiscal year $t$, we set monthly betas equal to the estimated coefficients, $\hat{\beta}_{R M R F, i, t}, \hat{\beta}_{H M L, i, t}$, and $\hat{\beta}_{S M B, i, t} \cdot{ }^{15}$

Second, we estimate the expected annual factor returns by first calculating each factor's average monthly return over the 60 months prior to month $m$, and then compounding the resulting average monthly returns over the twelve months prior to the beginning of firm $i$ 's fiscal year. ${ }^{16}$ We obtain our estimate of the annual expected equity cost of capital, ECC, for firm $i$ and year $t$ (based on data available at the beginning of year $t$ ) by multiplying the expected factor returns by their respective estimated factor loadings:

$$
E C C_{i t} \equiv \bar{R}_{f, t}+\hat{\beta}_{R M R F, i, t} *\left[\overline{R_{M}-R_{f}}\right]_{t}+\hat{\beta}_{H M L, i, t} *[\overline{H M L}]_{t}+\hat{\beta}_{S M B, i, t} *[\overline{S M B}]_{t}
$$

\footnotetext{
${ }^{15}$ Data availability limits the number of firms for which there are 60 months of data. Therefore, we require a minimum of 24 monthly returns to estimate equation (11).

${ }^{16}$ Because 60-month rolling windows may result in an outdated estimated risk-free rate, we calculate the expected monthly risk-free rate based on a 12-month rolling risk-free rate, updated monthly. The expected annual risk-free rate, $\bar{R}_{f, t}$, is obtained by compounding the expected monthly risk-free rate.
} 
where $\bar{R}_{f, t}$ is the expected annual risk-free rate for year $t+1$ and $\left[\overline{R_{M}-R_{f}}\right]_{t},[\overline{H M L}]_{t}$, and $[\overline{S M B}]_{t}$ are the expected annual factor returns for year $t+1$.

\subsection{EXPECTED EQUity Cost OF CAPITAL RESUlts}

Table 7 presents expected equity cost of capital results. ${ }^{17}$ Panels A and B tabulate ECC summary statistics for IAS and NIAS firms in the pre- and post-adoption periods. Panel A indicates that both IAS and NIAS firms have essentially the same, and statistically indistinguishable, mean $E C C$ in the pre-adoption period, $11.48 \%$ and $11.42 \%$. However, consistent with predictions, it also reveals that mean ECC for IAS firms is $0.77 \%$ lower than that for NIAS firms in the post-adoption period, $5.67 \%$ vs. $6.44 \%$, although the difference is not significant because of the large standard errors of the estimates. Panels C and D, which tabulate $E C C$ statistics separately for IAS and NIAS firms, indicate that mean $E C C$ is significantly smaller for both groups of firms in the post-adoption period than in the pre-adoption period. Yet, the decrease in $E C C$ is greater in magnitude (albeit insignificantly so) for IAS firms.

\section{Summary and Concluding Remarks}

Our results suggest that application of International of Accounting Standards is associated with improvement in accounting quality. In particular, firms that apply IAS generally show less evidence of earnings smoothing, less evidence of managing earnings towards a target, more timely recognition of losses, and a higher association of accounting amounts with share prices and returns. Our results are based on three comparisons of accounting quality. The first

\footnotetext{
${ }^{17}$ The smaller sample sizes in table 7 relative to other tables reflect the loss of sample years when estimating the parameters used to estimate $E C C$ in equation (11). In addition, to deal with extreme outliers, we effectively winsorize all $E C C$ estimates by setting $E C C$ to an average of the fitted value from equation (12) and the sample average $E C C$ for each year. Untabulated results based on the non-winsorized $E C C$ s reveal similar inferences to those drawn from table 7.
} 
compares accounting quality for firms applying IAS to that for firms that do not apply IAS in the period after the IAS firms adopt IAS. The second compares accounting quality for IAS firms to that for themselves in the periods before and after they adopt IAS. The third compares differences in changes in accounting quality for IAS firms and for firms that do not apply IAS between the period before and after the IAS firms adopt IAS. We also find weak evidence that applying IAS may be associated with a lower expected equity cost of capital. 


\section{REFERENCES}

Amihud, Y., and H. Mendelson. 1986. Asset Pricing and the Bid-Ask Spread. Journal of

Financial Economics 17: 223-249.

Ang, A., and J. Liu. 2004. How to Discount Cash Flows with Time-Varying Expected Returns. Journal of Finance 59: 2745-2783.

Ashbaugh, H. 2001. Non-U.S. Firms' Accounting Standard Choices. Journal of Accounting and Public Policy 20: 129-153

Ashbaugh, H., and P. Olsson. 2002. An Exploratory Study of the Valuation Properties of Crosslisted Firms' IAS and U.S. GAAP Earnings and Book Values. The Accounting Review 77: 107-126.

Ashbaugh, H., and M. Pincus, 2001. Domestic Accounting Standards, International Accounting Standards, and the Predictability of Earnings, Journal of Accounting Research 39: 417-434.

Ball, R., S.P. Kothari, and A. Robin. 2000. The Effect of International Institutional Factors on Properties of Accounting Earnings. Journal of Accounting and Economics 29: 1-51.

Ball, R.; A. Robin, and J.S. Wu. 2003. Incentives versus Standards: Properties of Accounting Income in Four East Asian Countries. Journal of Accounting and Economics 36: 235-270.

Barry, C. B., and S. J. Brown. 1985. Differential Information and Security Market Equilibrium. Journal of Financial and Quantitative Analysis 20: 407-422.

Barth, M.E., W.H. Beaver, and W.R. Landsman. 2001. The Relevance of the Value Relevance Literature for Accounting Standard Setting: Another View. Journal of Accounting and Economics 31: 77-104. 
Barth, M.E., Y. Konchitchki, and W.R. Landsman. 2006. Cost of Capital and Financial Statement Transparency. Working paper, Stanford University and University of North Carolina.

Bartov, E., S. Goldberg, and M. Kim. 2004. Comparative Value Relevance among German, U.S. and International Accounting Standards: A German Stock Market Perspective. Working paper, New York University.

Bhattacharya, U., H. Daouk, and M. Welker. 2003. The World Price of Earnings Opacity. Working paper, Queen’s University.

Botosan, C.A. 1997. Disclosure Level and the Cost of Equity Capital. The Accounting Review 7: 323-349.

Botosan, C.A., and M. Plumlee. 2002. A Re-examination of Disclosure Level and Expected Cost of Equity Capital. Journal of Accounting Research 40: 21-40.

Bradshaw, M.T., and G.S. Miller. 2005. Will Harmonizing Accounting Standards Really Harmonize Accounting? Evidence from Non-U.S. Firms Adopting US GAAP. Working paper, Harvard Business School.

Breeden, R. 1994. Foreign Companies and U.S. Markets in a Time of Economic Transformation. Fordham International Law Journal 17.

Burgstahler, D., and I. Dichev. 1997. Earnings Management to Avoid Earnings Decreases and Losses. Journal of Accounting and Economics 24: 99-126.

Cairns, D. 1999. Degrees of Compliance. Accountancy International (September): 68-69.

Clarkson, P., and R. Thompson. 1990. The Empirical Estimates of Beta when Investors Face Estimation Risk. Journal of Finance 45: 431-453. 
Coles, J. and U. Loewenstein. 1988. Equilibrium Pricing and Portfolio Composition in the Presence of Uncertain Parameters. Journal of Financial Economics: 279-303.

Covrig, V., M. DeFond and M. Hung. 2005. Cross-Border Investment and the Voluntary Adoption of International Accounting Standards. Working paper, University of Southern California.

Cramer, J.S. 1987. Mean and Variance of $\mathrm{R}^{2}$ in Small and Moderate Samples. Journal of Econometrics 35: 253-266.

Daske, H. 2006. Economic Benefits of Adopting IFRS or US-GAAP - Have the Expected Costs of Equity Capital Really Decreased? Journal of Business Finance and Accounting, forthcoming.

Easley, D., and M. O'Hara. 2004. Information and the Cost of Capital. Journal of Finance 59: $1,553-1,583$.

Eccher, E. and P. Healy, 2003. The Role of International Accounting Standards in Transitional Economies: A Study of the People's Republic of China. Working paper, Massachusetts Institute of Technology.

Ewert, R., and A. Wagenhofer. 2005. Economic Effects of Tightening Accounting Standards to Restrict Earnings Management. The Accounting Review 43: 1,101-1,124.

Fama, E.F., and K.R. French. 1993. Common Risk Factors in the Returns of Stocks and Bonds. Journal of Financial Economics 33: 3-56.

Francis, J., R. LaFond, P. Olsson, and K. Schipper. 2004. Costs of Equity and Earnings Attributes. The Accounting Review 79: 967-1,010.

Greene, W., 1993. Econometric Analysis. MacMillan, New York. 
Griffin, J.M. 2003. Are the Fama and French Factors Global or Country Specific? Review of Financial Studies 15: 723-750.

Handa, P., and S. Linn. 1993. Arbitrage Pricing with Estimation Risk. Journal of Financial Economics: 81-100.

Harris, M., and K. Muller. 1999. The Market Valuation of IAS versus US GAAP Accounting Measures Using Form 20-F Reconciliations. Journal of Accounting and Economics 26: 285312.

Healy, P.M. 1985. The Effect of Bonus Schemes on Accounting Decisions. Journal of Accounting and Economics 7: 85-107.

Hung, M. and K.R. Subramanyam. 2004. Financial Statement Effects of Adopting International Accounting Standards: The Case of Germany. Working paper, University of Southern California.

Klein, R., and V. Bawa. 1976. The Effect of Estimation Risk on Optimal Portfolio Choice. Journal of Financial Economics 3: 215-231.

Land, J., and M. Lang. 2002. Empirical Evidence on the Evolution of International Earnings. The Accounting Review 77: 115-134.

Lang, M., J. Raedy, and M. Yetman. 2003. How Representative are Firms that are Cross Listed in the United States? An Analysis of Accounting Quality. Journal of Accounting Research 41: 363-386.

Lang, M., J. Raedy, and W. Wilson. 2005. Earnings Management and Cross Listing: Are Reconciled Earnings Comparable to US Earnings? Journal of Accounting and Economics, forthcoming. 
Leuz, C. 2003. IAS Versus U.S. GAAP: Information Asymmetry-based Evidence from Germany's New Market. Journal of Accounting Research 41: 445-427.

Leuz, C.; D. Nanda; and P. Wysocki. 2003. Earnings Management and Investor Protection: An International Comparison. Journal of Financial Economics 69: 505-527.

Massa, M., U. Peyer, and Z. Tong. 2004. Limits of Arbitrage and Corporate Financial Policies. Working Paper, INSEAD.

Myers, L.A., and D.J. Skinner. 2002. Earnings Momentum and Earnings Management. Working paper, University of Michigan.

Pagano, M.; A. Röell; and J. Zehner. 2002. The Geography of Equity Listings: Why do Companies List Abroad? Journal of Finance 57: 2,651-2,694.

Street, D. and S. Gray. 2001. Observance of International Accounting Standards: Factors Explaining Non-Compliance. ACCA Research Report No. 74.

Tarca, A. 2004. International Convergence of Accounting Practices: Choosing between IAS and US GAAP. Journal of International Financial Management and Accounting 15: 60-91.

Van Tendeloo, B. and A. Vanstraelen. 2005. Earnings Management under German GAAP versus IFRS. European Accounting Review 14: 155-180.

Wysocki, P. 2005. Assessing Earnings and Accruals Quality: US and International Evidence. Working Paper, Massachusetts Institute of Technology. 
TABLE 1

Descriptive Statistics Relating to Application of IAS

\section{Panel A: Country Breakdown}

\begin{tabular}{|c|c|c|c|c|}
\hline & $\begin{array}{c}\text { Number of Firm- } \\
\text { Year } \\
\text { Observations }\end{array}$ & $\begin{array}{l}\text { Percentage of } \\
\text { Firm-Year } \\
\text { Observations }\end{array}$ & $\begin{array}{l}\text { Number of } \\
\text { IAS Firms }\end{array}$ & $\begin{array}{c}\text { Percentage of } \\
\text { IAS Firms }\end{array}$ \\
\hline Australia & 2 & 0.11 & 1 & 0.31 \\
\hline Austria & 111 & 5.89 & 17 & 5.33 \\
\hline Belgium & 23 & 1.22 & 5 & 1.57 \\
\hline China & 430 & 22.81 & 90 & 28.21 \\
\hline Czech Republic & 8 & 0.42 & 2 & 0.63 \\
\hline Denmark & 28 & 1.49 & 4 & 1.25 \\
\hline Finland & 37 & 1.96 & 3 & 0.94 \\
\hline Germany & 329 & 17.45 & 57 & 17.87 \\
\hline Greece & 12 & 0.64 & 2 & 0.63 \\
\hline Hong Kong & 53 & 2.81 & 10 & 3.13 \\
\hline Hungary & 59 & 3.13 & 10 & 3.13 \\
\hline Poland & 4 & 0.21 & 1 & 0.31 \\
\hline Portugal & 6 & 0.32 & 1 & 0.31 \\
\hline Russian Federation & 2 & 0.11 & 2 & 0.63 \\
\hline Singapore & 27 & 1.43 & 8 & 2.51 \\
\hline South Africa & 66 & 3.50 & 8 & 2.51 \\
\hline Spain & 3 & 0.16 & 1 & 0.31 \\
\hline Sweden & 3 & 0.16 & 1 & 0.31 \\
\hline Switzerland & 594 & 31.51 & 79 & 24.76 \\
\hline Turkey & 84 & 4.46 & 16 & 5.02 \\
\hline United Kingdom & 4 & 0.21 & 1 & 0.31 \\
\hline Total & 1,885 & 100.00 & 319 & 100.00 \\
\hline
\end{tabular}


TABLE 1

Descriptive Statistics Relating to Application of IAS

\section{Panel B: Industry Breakdown}

\begin{tabular}{lcccc} 
& $\begin{array}{c}\text { Number of } \\
\text { Firm-Year } \\
\text { Observations }\end{array}$ & $\begin{array}{c}\text { Percentage of } \\
\text { Firm-Year } \\
\text { Observations }\end{array}$ & $\begin{array}{c}\text { Number of } \\
\text { IAS Firms }\end{array}$ & $\begin{array}{c}\text { Percentage of } \\
\text { IAS Firms }\end{array}$ \\
\hline Agriculture, Forestry and & & & & \\
Fishing & 3 & 0.16 & 1 & 0.31 \\
Mining & 124 & 6.58 & 21 & 6.58 \\
Construction & 147 & 7.80 & 20 & 6.27 \\
Manufacturing & 951 & 50.45 & 152 & 47.65 \\
Utilities & 107 & 5.68 & 18 & 5.64 \\
Retail Trade & 55 & 2.92 & 8 & 2.51 \\
Finance, Insurance and & & & & \\
Real Estate & 296 & 15.70 & 51 & 15.99 \\
Services & 182 & 9.66 & 44 & 13.79 \\
Public Administration & 20 & 1.06 & 4 & 1.25 \\
Total & 1,885 & 100.00 & 319 & 100.00
\end{tabular}

Panel C: Year Breakdown

\begin{tabular}{ccccc} 
& $\begin{array}{c}\text { Number of } \\
\text { Firm-Year } \\
\text { Observations }\end{array}$ & $\begin{array}{c}\text { Percentage of } \\
\text { Firm-Year } \\
\text { Observations }\end{array}$ & $\begin{array}{c}\text { Number of } \\
\text { IAS Firms }\end{array}$ & $\begin{array}{c}\text { Percentage of } \\
\text { IAS Firms }\end{array}$ \\
\hline 1994 & 278 & 14.75 & 24 & 7.52 \\
1995 & 127 & 6.74 & 16 & 5.02 \\
1996 & 110 & 5.84 & 17 & 5.33 \\
1997 & 184 & 9.76 & 28 & 8.78 \\
1998 & 196 & 10.40 & 27 & 8.46 \\
1999 & 273 & 14.48 & 58 & 18.18 \\
2000 & 347 & 18.41 & 75 & 23.51 \\
2001 & 146 & 7.75 & 27 & 8.46 \\
2002 & 110 & 5.84 & 24 & 7.52 \\
2003 & 114 & 6.05 & 23 & 100.00 \\
& 1,885 & 100.00 & 319 & \\
\hline
\end{tabular}

Sample of firms that adopted International Accounting Standards (IAS) between 1994 and 2003. 
TABLE 2

Descriptive Statistics Relating to Variables used in Analyses

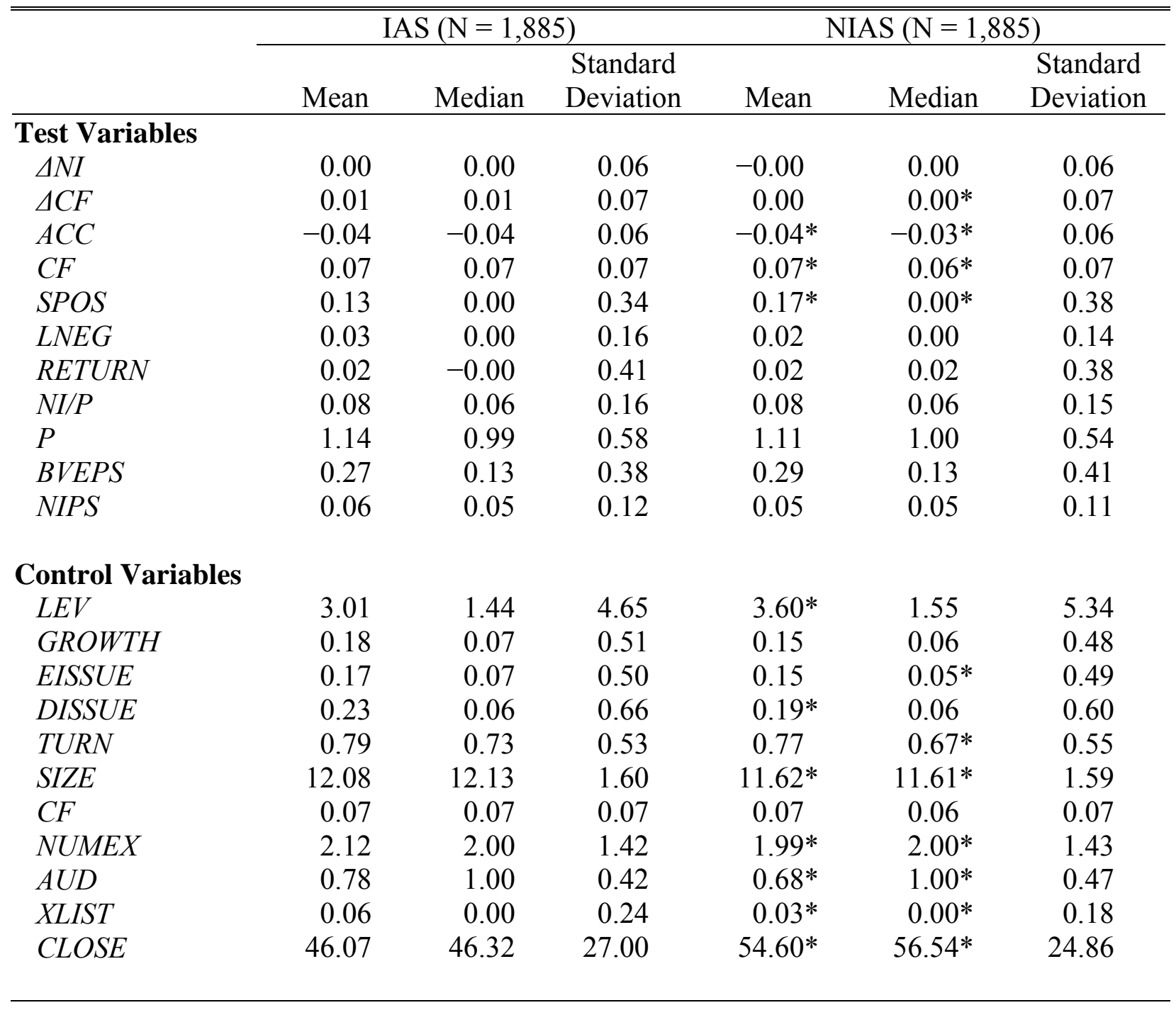

* Significantly different from IAS and NIAS at the 0.05 levels respectively (two-tailed).

Sample of firms that adopted International Accounting Standards (IAS) between 1994 and 2003 (IAS firms) and matched sample of firms that did not (NIAS firms). Tabulated statistics are from the years after IAS firms adopted IAS, i.e., the post-adoption period, which ends in 2003.

$\triangle N I$ is the change in annual earnings, where earnings is scaled by end-of-year total assets; $\triangle C F$ is the change in annual net cash flow, $C F$, where cash flow is scaled by end-of-year total assets; $A C C$ is earnings less cash flow from operating activities, scaled by end-of-year total assets; $C F$ is annual net cash flow from operating activities, scaled by end-of-year total assets; SPOS is an indicator that equals 1 for observations with annual earnings scaled by total assets between 0.00 and $0.01 ; L N E G$ is an indicator that equals 1 for observations with annual earnings scaled by total assets less than $-0.20, R E T U R N$ is annual stock return from nine months prior to three 
months after the firm's fiscal year end; $P$ is price as of six months after fiscal year-end; $N I / P$ is earnings per share scaled by beginning of year price; $B V E P S$ is book value of equity per share; NIPS is net income per share.

$L E V$ is end-of-year total liabilities divided by end-of-year book value of equity, GROWTH is annual percentage change in sales; EISSUE is annual percentage change in common stock; $D I S S U E$ is annual percentage change in total liabilities; TURN is sales divided by end-of-year total assets; SIZE is the natural logarithm of market value of equity in millions of dollars as of the end of the year; NUMEX is number of exchange listings; $A U D$ is an indicator that equals 1 if the auditor is one of the large international accounting firms; XLIST is an indicator that equals 1 if the firm is listed on any US stock exchange and WorldScope indicates that the US exchange is not the primary exchange; CLOSE as the percentage of closely held shares as reported by WorldScope. 
TABLE 3

Comparison of IAS and NIAS Firms' Accounting Quality in the Period After IAS Firms Adopt $I A S$

\begin{tabular}{lccc}
$\begin{array}{l}\text { Earnings Management } \\
\text { Measure }\end{array}$ & Prediction & $\begin{array}{c}\text { IAS } \\
(\mathrm{N}=1,298)\end{array}$ & $\begin{array}{c}\text { NIAS } \\
(\mathrm{N}=1,298)\end{array}$ \\
\hline Variability of $\triangle N I^{*}$ & IAS > NIAS & 0.0025 & 0.0021 \\
Variability of $\triangle N I^{*}$ over $\triangle C F^{*}$ & IAS > NIAS & 1.1076 & $1.0392^{\wedge}$ \\
Correlation of $A C C^{*}$ and $C F^{*}$ & IAS > NIAS & -0.5518 & $-0.5697^{*}$ \\
Small Positive NI $(S P O S)$ & - & & -0.0431
\end{tabular}

\section{Timely Loss Recognition}

Measure

Large Negative NI (LNEG)

$+\quad 0.1424 \#$

\section{Value Relevance}

Regression Adjusted $R^{2}$

$\begin{array}{llll}\text { Price } & \text { IAS }>\text { NIAS } & 0.4023 & 0.3035^{*} \\ \text { Good News } & \text { IAS }>\text { NIAS } & 0.0490 & 0.0214 \\ \text { Bad News } & \text { IAS }>\text { NIAS } & 0.0622 & 0.0739\end{array}$

*Significantly different between IAS and NIAS firms at the 0.05 level (one-sided).

\#Significantly different from zero at the 0.05 level (one-sided).

${ }^{\wedge}$ No test of significance of differences between IAS and NIAS firms.

Sample of firms that adopted International Accounting Standards (IAS) between 1994 and 2003 (IAS firms) and matched sample of firms that did not (NIAS firms). The periods after IAS firms adopted IAS, i.e., the post-adoption period, ends in 2003.

We base the analysis on industry and country fixed effect regressions including controls as defined in table 2. We define variability of $\Delta N I^{*}\left(\triangle C F^{*}\right)$ as the variance of residuals from a regression of the $\triangle N I(\triangle C F)$ on the control variables, and the variability of $\triangle N I^{*}$ over $\triangle C F^{*}$ as the ratio of the variability of $\triangle N I^{*}$ divided by the variability of $\triangle C F^{*}$. Correlation of $A C C^{*}$ and $C F^{*}$ is the partial Spearman correlation between the residuals from the $A C C$ and $C F$ regressions; we compute both sets of residuals from a regression of each variable on the control variables. $\triangle N I, \triangle C F, A C C$, and $C F$ are defined in table 2.

We regress an indicator variable that equals 1 for IAS firms and 0 for NIAS firms on SPOS ( $L N E G)$ and control variables. SPOS $(L N E G)$ is an indicator that equals 1 when annual net income scaled by total assets is between 0 and 0.01 (less than -0.20 ) and 0 otherwise; the coefficient on the indicator variable is tabulated. 
The price regression is based on a two-stage regression. In the first stage, $P$ is regressed on industry and country fixed-effect indicator variables, where $P$ is price as of six months after the fiscal year-end. The second stage regression is $P^{*}=\beta_{0}+\beta_{1} B V E P S+\beta_{2} N I P S+\varepsilon$, where $P^{*}$ is the residual from the first-stage regression, $B V E P S$ is book value of equity per share, and NIPS is net income per share. The good/bad news regression is based on a two-stage regression. In the first stage, $N I / P$ is regressed on industry and country fixed-effect indicator variables. The second stage regression is $N I / P^{*}=\beta_{1}$ RETURN $+\varepsilon$, where $N I / P^{*}$ is the residual from the first stage regression, and RETURN is stock return computed over the twelve months ending three months after year-end. Good (bad) news observations are those for which RETURN is nonnegative (negative). Adjusted $R^{2}$ is from the second-stage regressions. 
TABLE 4

Comparison of IAS and NIAS Firm's Accounting Quality in the Period Before IAS Firms Adopt IAS

\begin{tabular}{lcc}
$\begin{array}{l}\text { Earnings Management } \\
\text { Measure }\end{array}$ & $\begin{array}{c}\text { IAS } \\
(\mathrm{N}=587)\end{array}$ & $\begin{array}{c}\text { NIAS } \\
(\mathrm{N}=587)\end{array}$ \\
\hline Variability of $\triangle N I^{*}$ & 0.0016 & $0.0018^{*}$ \\
Variability of $\triangle N I^{*}$ over $\triangle C F^{*}$ & 0.6194 & $0.6661^{\wedge}$ \\
Correlation of $A C C^{*}$ and $C F^{*}$ & -0.6073 & $-0.5726^{*}$ \\
Small Positive NI (SPOS) & & -0.0713 \\
& & \\
Timely Loss Recognition & & \\
Measure & & \\
\hline Large Negative NI $(L N E G)$ & & \\
Value Relevance & & \\
Regression Adjusted $R^{2}$ & & \\
Price & & $0.3094 \#$ \\
Good News & & $0.0299^{*}$ \\
Bad News & 0.2803 & $0.0184^{*}$ \\
& 0.0224 &
\end{tabular}

*Significantly different between IAS and NIAS firms at the 0.05 level (one-sided). \#Significantly different from zero at the 0.05 level (one-sided).

${ }^{\wedge}$ No test of significance is of differences between IAS and NIAS firms.

Sample of firms that adopted International Accounting Standards (IAS) between 1994 and 2003 (IAS firms) and matched sample of firms that did not (NIAS firms). The period before IAS firms adopted IAS, i.e., the pre-adoption period, begins in 1990.

We base the analysis on industry and country fixed effect regressions including controls as defined in table 2 . We define variability of $\triangle N I^{*}\left(\triangle C F^{*}\right)$ as the variance of residuals from a regression of the $\triangle N I(\triangle C F)$ on the control variables, and the variability of $\triangle N I^{*}$ over $\triangle C F^{*}$ as the ratio of the variability of $\triangle N I^{*}$ divided by the variability of $\triangle C F^{*}$. Correlation of $A C C^{*}$ and $C F^{*}$ is the partial Spearman correlation between the residuals from the $A C C$ and $C F$ regressions; we compute both sets of residuals from a regression of each variable on the control variables. $\triangle N I, \triangle C F, A C C$, and $C F$ are defined in table 2 .

We regress an indicator variable that equals 1 for IAS firms and 0 for NIAS firms on SPOS $(L N E G)$ and control variables. SPOS $(L N E G)$ is an indicator that equals 1 when annual net income scaled by total assets is between 0 and 0.01 (less than -0.20) and 0 otherwise; the coefficient on the indicator variable is tabulated. 
The price regression is based on a two-stage regression. In the first stage, $P$ is regressed on industry and country fixed-effect indicator variables, where $P$ is price as of six months after the fiscal year-end. The second stage regression is $P^{*}=\beta_{0}+\beta_{1} B V E P S+\beta_{2} N I P S+\varepsilon$, where $P^{*}$ is the residual from the first-stage regression, $B V E P S$ is book value of equity per share, and NIPS is net income per share. The good/bad news regression is based on a two-stage regression. In the first stage, $N I / P$ is regressed on industry and country fixed-effect indicator variables. The second stage regression is $N I / P^{*}=\beta_{0}+\beta_{1} R E T U R N+\varepsilon$, where $N I / P^{*}$ is the residual from the first stage regression, and RETURN is stock return computed over the twelve months ending three months after year-end. Good (bad) news observations are those for which RETURN is nonnegative (negative). Adjusted $R^{2}$ is from the second-stage regressions. 
TABLE 5

Comparison of IAS Firms' Accounting Quality Before and After They Adopt IAS

\begin{tabular}{|c|c|c|c|c|}
\hline $\begin{array}{l}\text { Earnings Management } \\
\text { Measure }\end{array}$ & Prediction & $\begin{array}{c}\text { PRE } \\
(\mathrm{N}=587)\end{array}$ & & $\begin{array}{c}\text { POST } \\
(\mathrm{N}=1,298)\end{array}$ \\
\hline Variability of $\Delta N I^{*}$ & POST $>$ PRE & 0.0017 & & $0.0024 *$ \\
\hline Variability of $\triangle N I^{*}$ over $\triangle C F^{*}$ & POST $>$ PRE & 0.7442 & & $0.9980^{\wedge}$ \\
\hline Correlation of $A C C^{*}$ and $C F^{*}$ & POST $>$ PRE & -0.5726 & & $-0.5549 *$ \\
\hline Small Positive NI (SPOS) & - & & -0.0645 & \\
\hline \multicolumn{5}{|l|}{$\begin{array}{l}\text { Timely Loss Recognition } \\
\text { Measure }\end{array}$} \\
\hline Large Negative NI ( $L N E G)$ & + & & $0.1805 \#$ & \\
\hline \multicolumn{5}{|l|}{$\begin{array}{l}\text { Value Relevance } \\
\text { Regression Adjusted } R^{2}\end{array}$} \\
\hline Price & POST $>$ PRE & 0.2820 & & $0.4023^{*}$ \\
\hline Good News & POST $>$ PRE & 0.0224 & & $0.0490 *$ \\
\hline Bad News & POST $>$ PRE & 0.0464 & & $0.0622 *$ \\
\hline
\end{tabular}

*Significantly different between pre- and post-adoption periods at the 0.05 level (one-sided). \#Significantly different from zero at the 0.05 level (one-sided).

${ }^{\wedge}$ No test of significance is of differences between pre- and post-adoption periods.

Sample of firms that adopted International Accounting Standards (IAS) between 1994 and 2003 (IAS firms) and matched sample of firms that did not (NIAS firms). The period before IAS firms adopt IAS, i.e., pre-adoption period, begins in 1990. The period after IAS firms adopt IAS, i.e., the post-adoption period, ends in 2003.

We base the analysis on industry and country fixed effect regressions including controls as defined in table 2 . We define variability of $\triangle N I^{*}\left(\triangle C F^{*}\right)$ as the variance of residuals from a regression of the $\triangle N I(\triangle C F)$ on the control variables, and the variability of $\triangle N I^{*}$ over $\triangle C F^{*}$ as the ratio of the variability of $\triangle N I^{*}$ divided by the variability of $\triangle C F^{*}$. Correlation of $A C C^{*}$ and $C F^{*}$ is the partial Spearman correlation between the residuals from the $A C C$ and $C F$ regressions; we compute both sets of residuals from a regression of each variable on the control variables. $\triangle N I, \triangle C F, A C C$, and $C F$ are defined in table 2.

We regress an indicator variable that equals 1 for IAS firms and 0 for NIAS firms on $S P O S$ $(L N E G)$ and control variables. SPOS $(L N E G)$ is an indicator that equals 1 when annual net income scaled by total assets is between 0 and 0.01 (less than -0.20) and 0 otherwise; the coefficient on the indicator variable is tabulated. 
The price regression is based on a two-stage regression. In the first stage, $P$ is regressed on industry and country fixed-effect indicator variables, where $P$ is price as of six months after the fiscal year-end. The second stage regression is $P^{*}=\beta_{0}+\beta_{1} B V E P S+\beta_{2} N I P S+\varepsilon$, where $P^{*}$ is the residual from the first-stage regression, $B V E P S$ is book value of equity per share, and NIPS is net income per share. The good/bad news regression is based on a two-stage regression. In the first stage, $N I / P$ is regressed on industry and country fixed-effect indicator variables. The second stage regression is $N I / P^{*}=\beta_{0}+\beta_{1} R E T U R N+\varepsilon$, where $N I / P^{*}$ is the residual from the first stage regression, and RETURN is stock return computed over the twelve months ending three months after year-end. Good (bad) news observations are those for which RETURN is nonnegative (negative). Adjusted $R^{2}$ is from the second-stage regressions. 
TABLE 6

Comparison of IAS and NIAS Firms' Change in Accounting Quality From the Period Before IAS Firms Adopt IAS to After

\begin{tabular}{lcccc} 
Earnings Management & \multicolumn{3}{c}{ Post - Pre } & Post - Pre \\
Measure & Prediction & IAS & NIAS & Difference \\
\hline Variability of $\triangle N I^{*}$ & IAS $>$ NIAS & 0.0007 & 0.0001 & $0.0006^{*}$ \\
Variability of $\triangle N I^{*}$ over $\triangle C F^{*}$ & IAS > NIAS & 0.2538 & 0.1041 & 0.1497 \\
Correlation of $A C C^{*}$ and $C F^{*}$ & IAS $>$ NIAS & 0.0177 & -0.0263 & -0.0440 \\
Small Positive NI $(S P O S)$ & - & -0.0645 & -0.0908 & 0.0263
\end{tabular}

Timely Loss Recognition

Measure

\begin{tabular}{lllll}
\hline Large Negative NI $(L N E G)$ & + & 0.1805 & 0.2099 & -0.0294
\end{tabular}

Value Relevance

Regression Adjusted $R^{2}$

\begin{tabular}{lrrrr}
\hline Price & IAS > NIAS & 0.1202 & 0.0318 & 0.0885 \\
Good News & IAS > NIAS & 0.0265 & -0.0086 & 0.0351 \\
Bad News & IAS > NIAS & 0.0157 & 0.0556 & -0.0399
\end{tabular}

*Significantly different between IAS and NIAS firms at the 0.05 level (one-sided).

Sample of firms that adopted International Accounting Standards (IAS) between 1994 and 2003 (IAS firms) and matched sample of firms that did not (NIAS firms). The periods after IAS firms adopted IAS, i.e., the post-adoption period, ends in 2003. The pre-adoption period begins in 1990 and the post-adoption period ends in 2003. The sample comprises 1,298 (587) IAS and NIAS firms in the post- (pre-) adoption period.

We base the analysis on industry and country fixed effect regressions including controls as defined in table 2 . We define variability of $\triangle N I^{*}\left(\triangle C F^{*}\right)$ as the variance of residuals from a regression of the $\triangle N I(\triangle C F)$ on the control variables, and the variability of $\triangle N I^{*}$ over $\triangle C F^{*}$ as the ratio of the variability of $\triangle N I^{*}$ divided by the variability of $\triangle C F^{*}$. Correlation of $A C C^{*}$ and $C F^{*}$ is the partial Spearman correlation between the residuals from the $A C C$ and $C F$ regressions; we compute both sets of residuals from a regression of each variable on the control variables. $\triangle N I, \triangle C F, A C C$, and $C F$ are defined in table 2.

We regress an indicator variable that equals 1 for IAS firms and 0 for NIAS firms on SPOS $(L N E G)$ and control variables. SPOS (LNEG) is an indicator that equals 1 when annual net income scaled by total assets is between 0 and 0.01 (less than -0.20) and 0 otherwise; the coefficient on the indicator variable is tabulated. 
The price regression is based on a two-stage regression. In the first stage, $P$ is regressed on industry and country fixed-effect indicator variables, where $P$ is price as of six months after the fiscal year-end. The second stage regression is $P^{*}=\beta_{0}+\beta_{1} B V E P S+\beta_{2} N I P S+\varepsilon$, where $P^{*}$ is the residual from the first-stage regression, $B V E P S$ is book value of equity per share, and NIPS is net income per share. The good/bad news regression is based on a two-stage regression. In the first stage, $N I / P$ is regressed on industry and country fixed-effect indicator variables. The second stage regression is $N I / P^{*}=\beta_{0}+\beta_{1} R E T U R N+\varepsilon$, where $N I / P^{*}$ is the residual from the first stage regression, and RETURN is stock return computed over the twelve months ending three months after year-end. Good (bad) news observations are those for which RETURN is nonnegative (negative). Adjusted $R^{2}$ is from the second-stage regressions. 
TABLE 7

Comparison of Expected Equity Cost of Capital between IAS Firms and NIAS Firms

\begin{tabular}{lccc}
\hline \hline & & & \\
Panel A: Pre-adoption & Number of Firms & Mean & Standard Deviation \\
\hline IAS firms & 131 & 0.1148 & 0.0527 \\
NIAS firms & 129 & 0.1142 & 0.0535 \\
Difference & & 0.0006 &
\end{tabular}

Panel B: Post-adoption

\begin{tabular}{lrrr}
\hline IAS firms & 336 & 0.0567 & 0.1179 \\
\hline NIAS firms & 348 & 0.0644 & 0.0871 \\
Difference & & -0.0077 &
\end{tabular}

Panel C: IAS Firms

\begin{tabular}{lccc}
\hline Post-adoption & 336 & 0.0567 & 0.1179 \\
Pre-adoption & 131 & 0.1148 & 0.0527 \\
Difference & & $-0.0580^{*}$ &
\end{tabular}

Panel D: NIAS Firms

$\begin{array}{lccc}\text { Post-adoption } & 348 & 0.0644 & 0.0871 \\ \text { Pre-adoption } & 129 & 0.1142 & 0.0535 \\ \text { Difference } & & -0.0498^{*} & \end{array}$

*Significantly different from zero at the 0.05 level (one-sided).

Sample of firms that adopted International Accounting Standards (IAS) between 1994 and 2003 (IAS firms) and matched sample of firms that did not (NIAS firms). The periods after IAS firms adopted IAS, i.e., the post-adoption period, ends in 2003 . The pre-adoption period begins in 1990 and the post-adoption period ends in 2003.

Expected cost of equity capital is estimated using the three-factor Fama and French (1993) model. 